\title{
Crop residue degradation by fungi isolated from conservation agriculture fields under rice-wheat system of North-West India
}

\author{
Madhu Choudhary ${ }^{1,2} \cdot$ Parbodh C. Sharma $^{2} \cdot$ Hanuman S. Jat ${ }^{3} \cdot$ Vibha Nehra $^{1} \cdot$ \\ Andrew J. McDonald ${ }^{3}$ Neelam Garg ${ }^{1}$
}

Received: 15 June 2016/ Accepted: 7 November 2016/Published online: 11 November 2016

(c) The Author(s) 2016. This article is published with open access at Springerlink.com

\begin{abstract}
Purpose In North West-Indo Gangetic Plains (NW-IGP) of India in situ burning of crop residues is practiced by majority of farmers' which deteriorates soil and environmental quality. Fungi have the potential for lignocellulose degradation and can be used for the in situ decomposition of crop residues. Lignocellulose degrading fungal spp. were isolated and evaluated for the activity of lignocellulolytic enzymes.

Method The lignocellulose degrading fungi were isolated by appearance of zone on carboxy methyl cellulose (CMC) agar media and tannic acid (TA) media. Carboxy methyl cellulase, filter paperase, cellobiase, xylanase and laccase activity were estimated in submerged, as well as solid state fermentation using a mixture of rice and wheat straw in the ratio of 4:1. rice-wheat straw as substrate. The residue left after solid state fermentation was evaluated for carbon/nitrogen ratio, dry mass loss, and loss of cellulose, hemicellulose and lignin. Selected potential isolates were further tested in pot experiment for their effect on wheat plants. The interaction among isolates was also studied. Result After primary screening, 19 out of a total of 72 fungal isolates were selected based on their enzymatic
\end{abstract}

Electronic supplementary material The online version of this article (doi:10.1007/s40093-016-0145-3) contains supplementary material, which is available to authorized users.

Madhu Choudhary

madhunehra@rediffmail.com

Kurukshetra University, Kurukshetra, India

2 Division of Soil and Crop Management, ICAR-Central Soil Salinity Research Institute, Karnal, Haryana 132001, India

3 International Maize and Wheat Improvement Centre (CIMMYT), New Delhi, India activity profile and potential to degrade lignocellulosic residues in submerged fermentation. Out of these 19 isolates, 11 were further selected based on their enzymatic secretions in solid state fermentation. All the 11 strains were identified morphologically. Four fungal isolates (RPW 1/3, RPW 1/6, RPWM 2/2 and RZWM 3/2) showed higher enzymatic activities and more loss of dry mass and cell wall constituents over the other isolates. These isolates were identified by ITS region sequencing as Aspergillus flavus, Aspergillus terreus, Penicillium pinophilum and Alternaria alternata.

Conclusion This study revealed that fungal isolates may be used for managing crop residues in conservation agriculture based rice-wheat system of NW-IGP to eliminate ill effects of residue burning.

Keywords Conservation agriculture - Crop residues . Fungi $\cdot$ Lignocellulolytic activity

\section{Introduction}

Rice-wheat (RW) cropping system is one of the world's largest agricultural production systems, covering an area of about 26 million hectares (Mha) spread over the IndoGangetic Plains (IGP) in South Asia and China (Sarkar 2015). The conservation agriculture (CA) based management practices and diversified farming system approach not only saves natural resources but may help in improving productivity, growth of cereals, accelerating farm income, mitigating environment pollution and climate change effects on agriculture. In IGP of North-West (NW) India, management of voluminous rice residues $\left(8-10 \mathrm{tha}^{-1}\right)$ in RW fields is still a serious problem which stagnate the area extension under CA. In conventional RW system, wheat 
planting is generally delayed (by 2-3 weeks) because of little turn-around time between harvesting of rice and sowing of wheat and the presence of heavy loads of rice straw left on the field after combine harvesting. Among current options available to farmers for rice residue management before wheat sowing are: (1) in situ incorporation in the soil using rotavator; (2) removal or partial burning of loose residue followed by zero-till sowing of wheat in anchored residue; (3) full residue retention using happy seeder machine for sowing of wheat and; (4) in situ open field burning followed by conventional wheat sowing. About $40 \%$ of crop residues (CRs) in IGP are being disposed-off through open field burning due to unavailability of happy seeders for sowing under residue conditions and fast decomposing bioagents (Jain et al. 2014). Burning of crop residues result in emission of noxious air pollutants and greenhouse gases along with particulate matter and hydrocarbons which affect the atmospheric chemistry (Kanabkaew and Oanh 2011). CRs are good source of plant nutrients and organic matter (40\% of the total dry biomass constituted by C) and are important for stability of agricultural ecosystems (Dobermann and Fairhurst 2002).

Rice residue can be managed in situ by hastening the microbial decomposition so that zero-till machine is able to seed wheat into the residues without burning. Decomposition and $\mathrm{N}$ release from crop residues depend on autochthonous soil microbes, length of decomposition period, and soil and environmental conditions. Fungi are an important component of soil micro-biota in soil constituting more of the soil biomass (Ainsworth and Bisby 1995) than bacteria, depending on depth and nutrient conditions of soil. Fungi being filamentous in nature possess have an advantage in the decomposition of lignocellulosic waste as they possess ability to produce prolific spores that can quickly invade substrates and supported by a broad variety of enzymes with complementary catalytic activities (Lundell et al. 2010). Fungi play an important role in the degradation of agricultural wastes such as wheat straw (Dinis et al. 2009), rice straw (Chang et al. 2012), maize stover (Wan and Li 2010), and sugarcane residue (Maza et al. 2014). Moreover, mixed cultures can have greater influence on substrate colonization because of the higher production of enzymes and resistance to contaminant microbes compared to pure cultures. However, the most important factor in the use of mixed cultures is the strain compatibility, which will influence the overall performance of microbes, their organization, distribution, population size and the ecological balance of the communities. Hence, a compatible consortium of lignocellulolytic fungal might play an important role in the rapid degradation of rice straw (Kausar et al. 2010).
In view of the non-availability of a machine (e.g., Happy Seeder) on a commercial scale, there is a need to isolate and inoculate the CR degrading fungi for faster decomposition of rice straw before sowing of wheat to allow use of normal zero-till planters and reduce its adverse effect on wheat growth. Although, residue degrading fungi are already present in soil but their population vary greatly from place to place and field to field depending on the management, edaphic and environmental conditions. Our hypothesis is that isolation and augmentation of fast degrading autochthonous fungi from fields under RW systems will enhance their population density upon field inoculation. Therefore, present study was carried out, (1) to isolate and identify lignocellulolytic fungi in liquid and solid state fermentation from fields under CA based RW systems and (2) to study the effect of inoculation of the identified efficient fungal species on enzyme release, crop residue degradation potential, and growth and yield of wheat in NW IGP of India.

\section{Materials and methods}

\section{Sampling site}

The soil samples were collected from CSISA (Cereal Systems Initiative for South Asia) experimental research platform located at ICAR-Central Soil Salinity Research Institute (CSSRI), Karnal, Haryana, India $\left(29^{\circ} 70^{\prime} \mathrm{N}\right.$ latitude and $76^{\circ} 96^{\prime} \mathrm{E}$ longitude) in May, 2013 after four years of continuous RW system. Four treatment scenarios were designed based on various drivers of agricultural changes as described in Gathala et al. (2013). These scenarios varied in cropping systems, tillage, crop establishment methods, crop residue management and crop management practices. Four scenarios viz., (1) scenario I: rice (CT/TPR; conventional till/transplanted rice)-wheat (conventional till) system as in farmers' practice where rice and wheat residues were removed; (2) scenario II: rice-wheatmungbean (CT/TPR-ZT; zero-till-ZT) rotation where full $(100 \%)$ rice and mungbean, and anchored wheat residue retained on soil surface; (3) scenario III: rice-wheatmungbean (ZT-ZT-ZT) where full $(100 \%)$ rice and mungbean, and anchored wheat residue retained on soil surface; (4) scenario IV: maize-wheat-mungbean (ZT$\mathrm{ZT}-\mathrm{ZT}$ ) where maize $(65 \%)$ and full mungbean, and anchored wheat residue retained on soil surface. In northwestern IGP of India, scenarios II and III are important to fulfill the need of the food security. In both these scenarios (II and III), residue load for rice and wheat averaged 6 and 1.5 t/ha (dry weight basis), respectively. 


\section{Isolation and primary screening of lignocellulolytic fungi}

After harvesting of wheat, in May, 2013 soil samples were collected from 0 to $15 \mathrm{~cm}$ layer from each scenario. For soil sampling, plot of each scenario was divided into four grids $(10 \times 50-\mathrm{m})$. Within each grid, soil was collected from nine locations and composited to make the representative sample. After sieving the soil samples, fungi were isolated from fresh samples on potato dextrose agar (PDA), czapek-dox agar (CDA) and rose bengal agar (RBA) plates, each containing $30 \mu \mathrm{g} / \mathrm{mL}$ of chloramphenicol. The inoculated plates were incubated at $28 \pm 2{ }^{\circ} \mathrm{C}$ and fungal growth was observed daily for 7 days. Purified fungal isolates were named according to crops and their establishment method. These isolates were screened (primary) by qualitative analysis of both cellulolytic and lignolytic activities on the basis of zone formation in carboxy methyl cellulose (CMC) and tannic acid (TA) agar plates, respectively. The cellulolytic activity was detected using the CMC agar media and presence of polyphenol oxidase was tested using TA media proposed by Cruz-Hernandez et al. (2005) with some modifications in its preparation. Tannic acid and rest of the constituents were separately autoclaved and mixed after cooling of TA. A fungal inoculum disc of 5-mm was cut from the hyphal edge of 5-day-old PDA culture. Each inoculum disc was placed at the centre of the media plate and incubated at $32{ }^{\circ} \mathrm{C}$ for 7 days. The CMC media plates were stained with Gram's iodine for 3-5 min (Kasana et al. 2008). The ratio of halo zone diameter to colony diameter was calculated and expressed as Index of Relative Enzyme Activity (ICMC) (Peciulyte 2007). On TA agar plates appearance of a dark brown pigment was considered as an indicator of polyphenol oxidase (PPO) activity. The fungal isolates showing maximum zone formation on agar media were used for secondary screening by submerged fermentation.

\section{Secondary screening of lignocellulolytic fungal isolates by submerged fermentation}

Lignocellulolytic enzymes activity of fungal isolates from primary screening was estimated using Mandel and Weber medium (Mandels and Weber 1969) supplemented with $10 \mathrm{~g} / \mathrm{l}$ of powdered straw of rice and wheat (in the ratio of 4:1) at $\mathrm{pH} 7.0$ and incubated at $30{ }^{\circ} \mathrm{C}$ for 10 days. Since Scenario II is generally followed by farmers where $100 \%$ rice residue and partial wheat residues are left in fields for degradation, hence the culture media was supplemented with rice and wheat (4:1) powdered straw. At the end of incubation, contents of each flask were filtered and centrifuged. The supernatants were used for crude enzyme preparation.
Selection of lignocellulolytic fungal isolates by solid state fermentation

A $5.0 \mathrm{~g}$ of rice and wheat straw mixture (4:1) was moistened with $15.0 \mathrm{ml}$ of Reese's mineral medium (Reese and Mandels 1963) in a $250 \mathrm{ml}$ flask was inoculated with isolates showing higher enzymatic activity in submerged fermentation. At 7 days after incubation at $30{ }^{\circ} \mathrm{C}$, the enzyme was extracted using citrate buffer $(0.05 \mathrm{M}, \mathrm{pH} 4.8)$ and centrifugation at $9000 \mathrm{rpm}$ for $10 \mathrm{~min}$ at $4{ }^{\circ} \mathrm{C}$. The supernatant was used for estimation of enzymatic activities. The remaining solid residue was dried at $75{ }^{\circ} \mathrm{C}$ for $24 \mathrm{~h}$ and weighed for dry mass loss estimation. Degradation of straw was expressed as dry mass loss (\%) and calculated as the difference between the dry mass of substrates with and without inoculation (Saparrat et al. 2008).

\section{Biochemical analysis of crop residues}

Cell wall components of the mixed straw were determined using the method described by AOAC (1995). The ovendried residue samples were ground to pass 40 mesh for analyzing different cell wall fractions. The fiber fractions of cell wall of the straw mixture such as cellulose, hemicellulose and lignin were estimated following the method of Van Soest et al. (1991). Both C and N were determined by CHNS analyser (Element Vario III) and $\mathrm{C}$ to $\mathrm{N}$ ratio was calculated.

\section{Enzyme assay}

Carboxy methyl cellulase or Endo- $\beta-1,4$-glucanase (EC 3.2.1.4), Filter paperase, Cellobiase (EC 3.2.1.21) and endo- $\beta$-1,4-xylanase (EC 3.2.1.8) were measured as per the procedure described by Ghose (1987) and Ghose and Bisaria (1987) using CMC, Whatman No.1 filter paper, cellobiose, and beech wood xylan as substrates, respectively. Dinitrosalicylic acid (DNS) method (Miller 1959) was used to determine reducing sugars. Laccase or $p$-diphenol oxidase (EC 1.10.3.2) was estimated by the modified method of Sandhu and Arora (1985). The relative activity of laccase was expressed as colorimetric units per gram of substrate $(\mathrm{cu} / \mathrm{g})$.

\section{Pot experiment}

Pot experiment was conducted to test the pathogenicity of isolates on wheat crop. Recommended package of practices of wheat were followed during the whole life cycle (Bajwa 2012). Pots of $30 \mathrm{~cm}$ in diameter and $45 \mathrm{~cm}$ in height were filled with $10 \mathrm{~kg}$ of soil and 15 seeds of wheat were sown in each pot. Liquid culture of 
all the 11 isolates screened from 72 isolates was prepared in potato dextrose broth (PDB) by inoculating three discs $(5 \mathrm{~mm}$ diameter) of fungal isolates. Liquid culture was applied at three times during wheat growth, i.e., immediately after sowing, at the time of first irrigation (21 DAS; days after sowing) and at second irrigation applied at 45 DAS.

All experiments were done in triplicate and the mean of three is presented in results.

\section{Identification of fungal isolates}

Fungal isolates was identified by observing and recording the cultural characteristics such as color and size of colony, mycelia growth and change in media color during growth. Isolates were also microscopically analyzed for morphological properties (shape, surface, margin and pigmentation). Fungal isolates were identified using standard manuals (Domsch et al. 1980; Gilman 2001; Nagamani et al. 2006). Selected fungal isolates were also identified by sequence analysis of rDNA gene. The DNA extraction was done using a modified CTAB (Cetyl trimethylammonium bromide) method (Edward et al. 1991). The rDNA region consisting of internal transcribed region (ITS) 1, 5.8S subunit and ITS 2 region, was amplified using ITS 1 and ITS 4 primers (Gardes and Bruns 1993). The PCR reaction was carried using $2.5 \mathrm{mM}$ dNTPs, $1.5 \mathrm{mM} \mathrm{MgCl} 2,10 \mathrm{p}$ moles each of forward and reverse primer and $1 \mathrm{U}$ of Taq DNA polymerase. The PCR thermal profile consisted of initial denaturation at $94{ }^{\circ} \mathrm{C}$ for $5 \mathrm{~min}$, followed by 35 cycles of denaturation at $94{ }^{\circ} \mathrm{C}$ for $30 \mathrm{~s}$, annealing at $53{ }^{\circ} \mathrm{C}$ for $1 \mathrm{~min}$, extension at $72{ }^{\circ} \mathrm{C}$ for $1 \mathrm{~min}$, followed by final extension at $72{ }^{\circ} \mathrm{C}$ for $7 \mathrm{~min}$. The PCR products were purified using gel extraction kit (Bioserve Biotechnologies Ltd., India) and checked on agarose gel electrophoresis $(1.5 \%)$ for its purity and integrity. The purified PCR products were then used directly for DNA sequencing. Sequence homology was analyzed using the BLAST search and compared with the sequences reported in GenBank. Sequence-based identities with the best hit were defined as the sequences with the highest maximum identity to the query sequence.

\section{Interaction study of isolates}

Interaction study of selected four isolates was done on PDA. Mycelium discs of $5 \mathrm{~mm}$ were cut from 5 days old culture. In one plate one disc of each two isolates were placed $40 \mathrm{~mm}$ apart from each other. The co-inoculated plates were incubated at $30{ }^{\circ} \mathrm{C}$ for 5-7 days. Interactions were noted according to the procedure described by Molla et al. (2001).

\section{Data analysis}

The data was subjected to ANOVA (analysis of variance) and tested for its significance using LSD (least significant difference) at $P=0.05$ by PC-SAS software (SAS Institute, Cary, NC, USA, 2001). For grouping of fungal isolates on the basis of their biochemical activities, the data were subjected to Group Average Clustering by STATGRAPHICS to obtain a dendrogram. The clustering was also obtained on basis of similarity in the sequences of amplified ITS region of fungal strains by ClustalW program.

\section{Results and discussion}

\section{Isolation of fungi and primary screening for lignocellulolytic activity}

A total of 72 fungi were isolated from experimental plots. Twenty of these isolates were from scenario I, 14 from scenario II, 17 from scenario III and 21 from scenario IV. All isolates had varying potential to produce clear zone around colony on CMC agar plates. The fungal isolates RPW1/1, RPW1/3, RPW1/8, RPW1/9, RPW1/10, RPWM2/5, RZWM3/2, RZWM3/4, and MWM4/7 showed ICMC $>1$ whereas RPW1/6, RPWM2/2, RPWM2/4, RZWM3/1, MWM4/6, MWM4/8, MWM4/9 and MWM4/ 13 showed ICMC $>0.5$ (supplementary Table 1 ). Out of 72 cultures, 21 cultures produced dark brown zone around colony on TA media which indicated their ability to produce PPO. This mixture of PPO enzymes (monophenol oxidase and catechol oxidase) catalyzes the reaction between polyphenol and oxygen to form dark brown-black complexes, which play a crucial role in the degradation of phenolic compounds in lignin (Kausar et al. 2010). Only a few isolates showed zone formation in both CMC and TA agar plates. Isolates having ICMC $>0.5$ (irrespective of zone on TA media plates) and isolates having very good dark brown zone (MWM4/5 and MWM4/14) were selected for further secondary screening. Lignin degradation is a critical step in the bioconversion of lignocellulosic materials in rice straw, because cellulose and hemicellulose are coated and protected from biodegradation by cellulases. Hence, it becomes important to isolate and screen the fungal strains having potential for lignin degradation.

\section{Secondary screening of fungi in rice-wheat straw amended broth}

Primarily screened 19 isolates were selected for quantitative estimation of enzymatic activity in broth amended with mixed straw powder of rice and wheat (4:1 ratio) as a 
carbon source. Fungi have the ability to decompose cellulose, hemicellulose and lignin in plants by secreting various sets of hydrolytic and oxidative enzymes (AbdElzaher and Fadel 2010). Synergistic action of cellulose degrading enzymes (endoglucanases, exoglucanases, cellobiohydrolases and glucosidases) will result in effective biodegradation of cellulose to glucose (Lynd et al. 2002). Cellulose being the main component of the cereal residues, screening is a critical step for the selection of isolates which can rapidly degrade cellulose. Cellobiases or betaglucosidases are the enzymes that participate in hydrolysis of $\beta(1 \rightarrow 4)$ linkage and hydrolyse the exocellulose product into individual monosaccharide units. In our study isolate RPW 1/10 showed maximum cellobiase activity $(0.374 \mathrm{IU} / \mathrm{ml})$. Isolate MWM 4/7 showed maximum activities of enzymes CMCase $(0.512 \mathrm{IU} / \mathrm{ml})$ and xylanase $(1.689 \mathrm{IU} / \mathrm{ml})$ and isolate RPWM $2 / 2$ showed maximum FPase activity $(0.167 \mathrm{IU} / \mathrm{ml})$ among all the isolates (Fig. 1). Although, the enzyme activities shown by the isolates MWM 4/5 and MWM 4/14 were low (Fig. 1), but they showed a significant brown zone production in primary screening. Therefore, these isolates were also selected for secondary screening. The isolate MWM 4/5 had a very low radial growth rate (data not shown) making it difficult to produce enzymes for assay and therefore, was not selected for further study. Laccase activity was found negligible in all isolates in liquid state fermentation. It might be due to secretion of laccase is too much low that it could not be detected in liquid state. On the basis of different enzyme (cellobiase, CMCase, FPase and xylanase) production potential of the 19 fungal isolates, the cluster analysis was carried out and a dendrogram was generated by STATGRAPHICS and Group Average Clustering Method (Fig. 2). Based on the cluster analysis two major groups were identified. Group 1 comprised ten members and Group 2 has nine. Group 1 has higher enzyme activities than Group 2. On the basis of enzymatic activities, all isolates of Group 1 and MWM 4/14 and RZWM 3/2 of Group 2 were selected for solid state fermentation. RZWM $3 / 2$ was the only isolate which exhibited all enzymatic activities, as well as good brown zone formation in primary screening. Although MWM 4/14 was poor in enzyme activity but showed high brown zone formation in primary screening, and was included in further studies.

\section{Lignocellulolytic activity in solid state fermentation}

In total, 12 isolates were selected for solid state fermentation, but in later stages, isolate RPW 1/1 was lost during experimentation due to unavoidable reasons. Therefore, only 11 isolates were used for further study. Enzyme activities of 11 fungal strains were estimated in extract of fermented solid media. Isolate RPWM $2 / 2$ which was earlier identified as Penicillium janthinellum by morphological characteristics but later identified (by ITS sequences) as Penicillium pinophilum showed maximum CMCase, Fpase and xylanase activity but lower laccase activity (Fig. 3). Zeng et al. (2006) reported that lignocellulose degradation by soil fungus Penicillium simplicissum improved when laccase activity was relatively low. Isolates MWM 4/9 and MWM 4/13 were identified as Penicillium oxalicum. Jorgensen and Olsson (2006) reported that several species of Penicillium were shown to have the ability to produce cellulolytic enzyme systems. Krogh et al. (2004) investigated 12 filamentous fungi from genus Penicillium for the production of cellulolytic and xylanolytic enzymes and found some Penicillium spp. as good producers of enzymes. Many species of Penicillium has been reported as good producer of xylanase (Chavez et al. 2006) like Penicillium janthinellum (Milagres et al. 1993), Penicillium oxalicum (Liao et al. 2012) Penicillium janczewskii (Terrasan et al. 2010). Isolates RZWM 3/2 and
Fig. 1 Enzyme activities (IU/ $\mathrm{ml}$ ) of fungal isolates under submerged fermentation

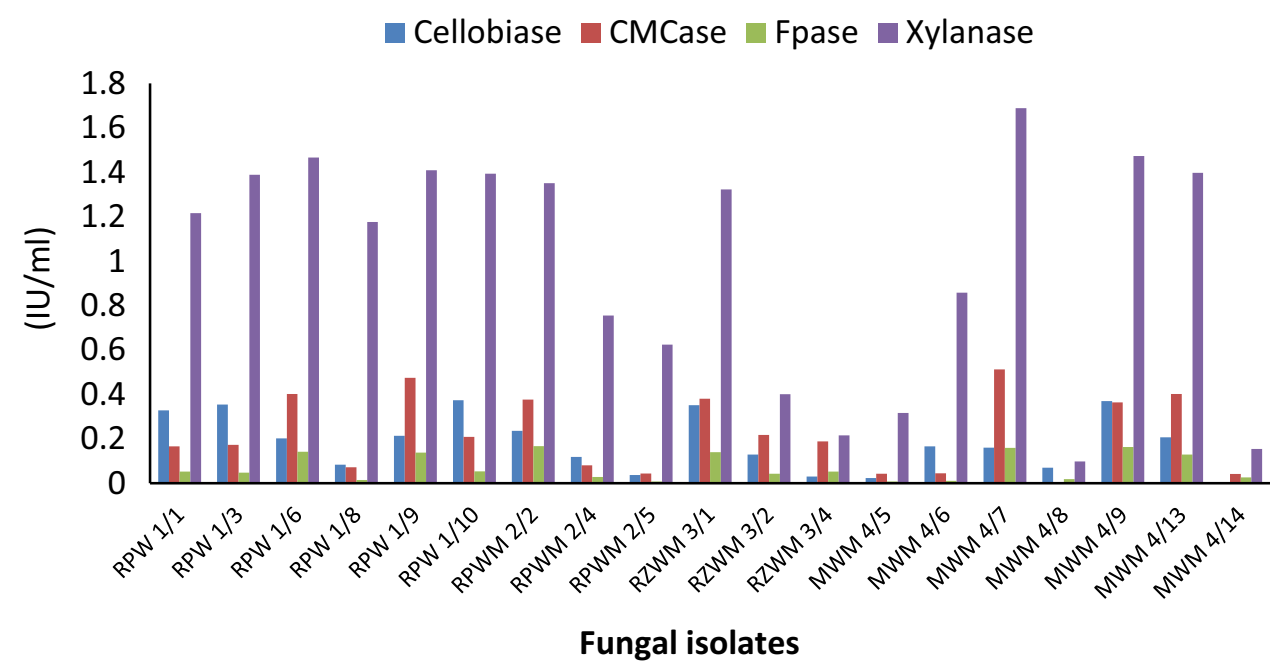


Fig. 2 Dendrogram representing 19 fungal isolates on basis of their enzymatic activity

Fig. 3 Enzyme activities of isolates in solid state fermentation (IU/g of substrate)
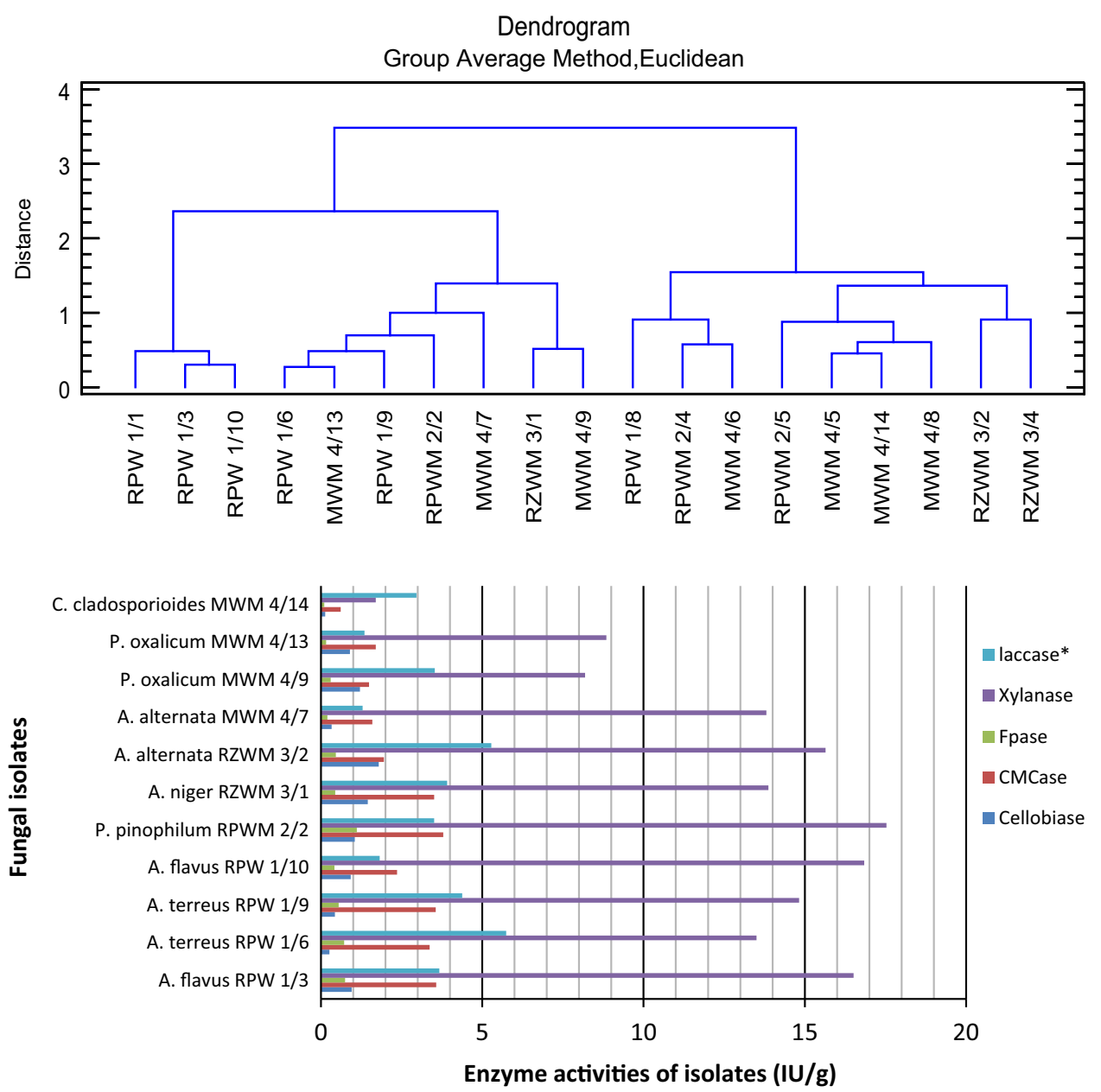

MWM 4/7 belonging to Alternaria alternate. Isolates RZWM 3/2 showed highest activities of both cellobiase and laccase enzymes (Fig. 3). Sohail et al. (2011) reported that Alternaria sp.MS28 has the ability to produce cellulases in presence of various substrates. The endophytic fungi Alternaria alternata also have been reported to produce xylanase (Wipusaree et al. 2011).

No significant difference was recorded in laccase activity of RZWM 3/2 and RPW 1/6. Based on morphological and cultural characteristics, RPW 1/3 and RPW 1/10, RPW 1/6 and RPW 1/9, and RZWM 3/1 were identified as Aspergillus flavus, Aspergillus terreus and Aspergillus niger, respectively. Many Species of Aspergilli produces cellulases and exhibits strong hydrolytic activity towards cellulose (Ogbonna et al. 2015). Some species of Aspergilli like A. flavus (Saritha and Maruthi 2010), A. niger (Chinedu et al. 2008) and A. terreus (Jahromi et al. 2011) were found effective in the biodegradation of different lignocellulosic materials by producing oxidative and hydrolytic enzymes. A. niger is known globally for its ability to produce broad range of extracellular glucohydrolases, including xylanases, pectinases, and $\beta$-glucosidase (Ward et al. 2005). This is because of the potential of fungus to propagate and colonize a variety of environments, principally those rich in decomposing plant material (Meijer et al. 2011). Ability of A. niger to decompose various lignocellulosic substrates like wheat straw (Kaur and Sahota 2004), rice straw (Lee et al. 2011) and litter (Song et al. 2010) has been reported. Aspergillus terreus was reported as good producer of xylanase but having lower activity of cellulase in liquid medium having wheat bran as carbon source (Sorgatto et al. 2012). Production of cellulases by A. terreus in fermentation of different substrates was reported by many authors like oil plam empty fruit bunch fiber (Shahriarinour et al. 2011), rice straw and sugar cane bagasse (Kumar and Parikh 2015).

The fungal isolate MWM 4/14 was identified as Cladosporium cladosporioides. This isolate did not show good activities of any enzyme but Lynch et al.(1981) reported cellulase activity in Cladosporium cladosporioides, whereas Jin et al. (2012) reported both cellulase, as well as laccase activity. 
Effect of selected fungal isolates on crop residue decomposition

Among the isolates, highest residue loss was realized with A. flavus RPW 1/3 (31\%) followed by A. terreus RPW 1/6 $(29 \%)>$ Alternaria alternata RZWM $3 / 2 \quad(26 \%)>P$. janthinellum RPWM 2/2 $(21 \%)>P$. oxalicum MWM 4/13 (18\%) and lowest loss was observed with C. cladosporioides MWM 4/14 (2\%) (Fig. 4). Similar results were also reported by Sinegani et al. (2005) who recorded $21.1 \%$ loss in weight of rice residue after 3 weeks with A. terreus.

\section{Effect of fungal isolates on loss of cell wall constituents}

Maximum cellulose loss was recorded with $A$. terreus RPW 1/6 (42.06\%) and A. flavus RPW 1/3 (41.90\%) followed by $P$. janthinellum RPWM 2/2 (37.10\%) and $A$. alternata RZWM 3/2 (33.31\%) (Table 1). Similarly, hemicellulose was lost maximum with A. terreus RPW 1/6 (44.69\%) followed by $P$. janthinellum RPWM $2 / 2$ (41.38\%), A. flavus RPW 1/3 (36.95\%), A. alternata RZWM 3/2 (31.01\%). Lignin loss was maximum in case of A. alternata RZWM 3/2 (16.52\%) followed by A. flavus RPW 1/3 (15.23\%), A. terreus RPW 1/9 (13.65) and $A$. flavus RPW 1/10 (12.74\%). Isolates which showed more dry mass loss (Fig. 4) also showed more loss of cell wall constituents (Table 1). Our study showed that Aspergillus spp. are good lignocellulosic degrader. It was found that higher degree of cellulose and hemicelluloses loss was recorded by some isolates but degree of lignin loss was comparatively low. Consistent with the results from our study, Chang et al. (2012) also reported that isolates showing higher degree of cellulose and hemicelluloses loss in general do not exhibit lignin loss, For example, it was reported that Fusarium moniliforme showed high degree of lignin degradation $(34.7 \%)$ while holocellulose degradation was low $(2.1 \%)$. In another fungal species Penicillium ochrochloron $Y 5$ has more cellulose and hemicellulose degradation was observed as compared with lignin degradation of wheat straw by $43.5,49.7$ and $9.3 \%$ after 10 days incubation (Yin et al. 2011). Reanprayoon (2011) found that weight loss of rice straw was between 50 and $70 \%$ by Aspergillus niger and in thermophilic condition cellulose, hemicellulose and lignin contents decreased by more than $80 \%$ after three weeks.

\section{Effect of fungal isolates on carbon and nitrogen contents and their ratio in treated rice and wheat straw}

The isolates RPW 1/3, RPW 1/6, RPWM 2/2 and RZWM $3 / 2$ showed similar and lowest $\mathrm{C}$ content $(37 \%)$ in the straw mixture (Table 1). During the process of biodegradation organic carbon is converted to $\mathrm{CO} 2$ and energy as metabolic end products. Consequently, total carbon content of substrate decreases as degradation progresses. $\mathrm{N}$ content was highest $(0.90 \%)$ in RPWM $2 / 2$ treated sample followed by RZWM $3 / 2(0.81 \%)$ and RPW $1 / 3(0.78 \%)$. The increase in total nitrogen content might be due to the synthesis of new cell structure, enzymes and hormones by microorganisms (Zhu 2007). The C:N ratio of crop residue is a key factor for its degradation. During the initial decomposition phase, low $\mathrm{C}: \mathrm{N}$ ratio causes manifold increase in the decomposition rate (Golueke 1992). Fungal isolate $P$. janthinellum RPWM $2 / 2$ showed maximum decrease in C:N ratio up to $33 \%$ as compared to the control (Table 1). Sharma et al. (2014) suggested the use of
Fig. 4 Dry mass loss of residue after solid state fermentation. The data represent the average of triplicates and the result is reported as the mean $\pm \mathrm{SD}$

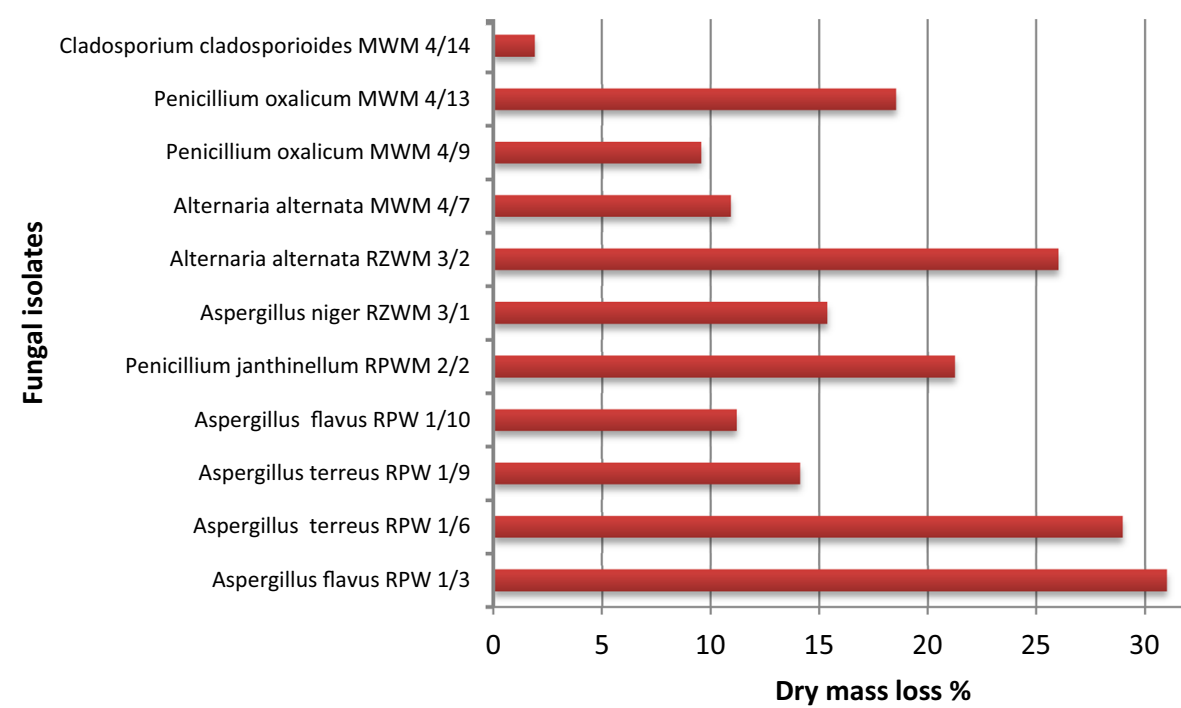

35 
Table 1 Effect of fungal inoculants on loss of cell wall constituents, and changes in carbon and nitrogen contents and C:N ratio in the mixture of rice and wheat straw $(4: 1)$

\begin{tabular}{|c|c|c|c|c|c|c|}
\hline Isolate & Cellulose loss, $\%$ & Hemicellulose loss, $\%$ & Lignin loss, $\%$ & $\mathrm{C}, \%$ & $\mathrm{~N}, \%$ & $\mathrm{C} / \mathrm{N}$ ratio \\
\hline A. flavus RPW 1/3 & $41.90 \mathrm{a}$ & $36.95 \mathrm{c}$ & $15.23 b$ & $37.15 d$ & $0.78 \mathrm{bc}$ & $47.68 \mathrm{de}$ \\
\hline A. terreus RPW $1 / 6$ & $42.06 \mathrm{a}$ & $44.69 \mathrm{a}$ & $9.49 \mathrm{f}$ & $37.27 \mathrm{~d}$ & $0.73 \mathrm{bcd}$ & $50.92 \mathrm{cde}$ \\
\hline A. terreus RPW 1/9 & $27.12 \mathrm{~d}$ & $24.50 \mathrm{f}$ & $13.65 \mathrm{c}$ & $39.08 b$ & $0.72 \mathrm{bcd}$ & $54.34 \mathrm{bcd}$ \\
\hline A. flavus RPW 1/10 & $20.53 f$ & $18.02 \mathrm{~g}$ & $12.74 d$ & $38.31 \mathrm{c}$ & $0.69 \mathrm{~cd}$ & $55.82 \mathrm{abc}$ \\
\hline P. janthinellum RPWM $2 / 2$ & $37.10 \mathrm{~b}$ & $41.38 b$ & $0.40 \mathrm{j}$ & $37.23 \mathrm{~d}$ & $0.90 \mathrm{a}$ & $41.54 \mathrm{f}$ \\
\hline A. niger RZWM 3/1 & $24.83 \mathrm{e}$ & $17.15 \mathrm{~g}$ & $10.05 \mathrm{e}$ & $38.33 \mathrm{c}$ & $0.70 \mathrm{~cd}$ & $54.68 \mathrm{bcd}$ \\
\hline A. alternata RZWM $3 / 2$ & $33.31 \mathrm{c}$ & $31.01 \mathrm{~d}$ & $16.52 \mathrm{a}$ & $37.52 \mathrm{~d}$ & $0.81 b$ & $46.94 \mathrm{e}$ \\
\hline A. alternata $\mathrm{MWM} 4 / 7$ & $21.93 \mathrm{e}$ & $16.07 \mathrm{~h}$ & $1.28 \mathrm{i}$ & $40.09 \mathrm{a}$ & $0.69 \mathrm{~cd}$ & $58.67 \mathrm{ab}$ \\
\hline P. oxalicum MWM 4/9 & $21.11 \mathrm{ef}$ & $28.17 \mathrm{e}$ & $1.11 \mathrm{i}$ & $38.80 \mathrm{bc}$ & $0.67 \mathrm{~d}$ & $58.44 \mathrm{ab}$ \\
\hline P. oxalicum MWM 4/13 & $27.55 \mathrm{~d}$ & $28.51 \mathrm{e}$ & $3.40 \mathrm{~h}$ & $39.91 \mathrm{a}$ & $0.68 \mathrm{~d}$ & $58.80 \mathrm{ab}$ \\
\hline C. cladosporioides MWM 4/14 & $10.18 \mathrm{~g}$ & $14.10 \mathrm{i}$ & $5.83 \mathrm{~g}$ & $38.94 \mathrm{bc}$ & $0.67 \mathrm{~d}$ & $57.81 \mathrm{abc}$ \\
\hline Control & $4.64 \mathrm{~h}$ & $3.28 \mathrm{j}$ & $0.00 \mathrm{k}$ & $40.60 \mathrm{a}$ & $0.65 \mathrm{~d}$ & $62.16 \mathrm{a}$ \\
\hline
\end{tabular}

Small alphabets followed in a column shows significant differences amongst isolates at $5 \%$ level of significance

different fungal, bacterial and actinomycetes inoculants to hasten the composting process of rice straw by lowering C:N ratio to $15: 1$ within 60 days of incubation. Significant reduction in cellulose and lignin content were reported in rice straw inoculated with mixed culture of Rhizopus oryzae, Aspergillus oryzae and Aspergillus fumigatus as compared to their individual application. Mixed culture of these three fungal strains also reduced $\mathrm{C}: \mathrm{N}$ ratio to $10: 1$ compared to $70: 1$ in rice straw mixed with soil (Viji and Neelenarayanan 2015). Although direct transformation of CRs in fields is an alternative for their cost effective utilization but bulky undecomposed residues can lead to unfavourable effects on successive crop growth and yields due to production of certain phytotoxic allelo chemicals (Inderjit et al. 2004). Therefore, a best possible alternative to manage CRs is its bioconversion through the action of hydrolytic enzymes produced by lignocellulolytic microorganisms (Vuorinen 2000; Tuomela et al. 2000).

\section{Evaluation of selected fungal isolates in wheat}

Results from our pot study indicated that none of the isolates showed any deleterious effect of pathogenicity in growth, yield attributes and grain yield of wheat (Table 2). Number of plants/pot ranged from 10 to 11.33 in different isolates. However, yield attributes like number of effective tillers/pot, spike length, number of grains/spike and 1000 grain weight was either similar or significantly higher in pots treated with different isolates compared to untreated control. Significantly higher wheat grain yield was recorded with majority of the isolates, except $P$. oxalicum MWM 4/9 and P. oxalicum MWM 4/13 compared to control treatment. While isolates A. flavus RPW 1/3 (61.76 g), A. terreus RPW 1/6 (61.40 g) and A. terreus
RPW 1/9 (64.51 g) produced the maximum yield, lowest yield was recorded for $P$. oxalicum MWM 4/13 (47.38 g) and control 1 (49.28 g). The increase in wheat yield might be due to degrading potential of isolate which helped in making increased availability of nutrients to the crop plants. The increase in wheat yield by different isolates was due to the combined effect of more number of effective tillers/pot, increase in number of grains per spike and grain size.

\section{Molecular identification}

Amongst different isolates evaluated, isolates RPW 1/3, RPW 1/6, RPWM 2/2 and RZWM 3/2 showed best results in terms of enzyme activities, as well as dry mass loss of straw. The molecular identification of these four fungal isolates was carried out by ITS region sequencing and sequences submitted to NCBI GenBank with accession numbers (KR363622, KR363623, KR363624 and KT818505). The BLAST search showed 99, 97, 99 and $100 \%$ similarity with Aspergillus flavus, Aspergillus terreus, Talaromyces pinophilus (anamorph: Penicillium pinophilum) and Alternaria alternata, respectively. All of the species identified by ITS sequencing further supports the morphological analysis showing the robustness of the morphological identification except strain RPWM 2/2. RPWM 2/2 earlier identified as Penicillium janthinellum but by molecular method was identified as Penicillium pinophilum.

\section{Interaction between selected isolates}

Interactions between different isolates were observed in our study (Table 3). All the interactions (except between $P$. 
Table 2 Effect of fungal isolates on growth, yield attributes and grain yield of wheat

\begin{tabular}{|c|c|c|c|c|c|c|}
\hline Treatments & $\begin{array}{l}\text { Number of } \\
\text { plants/pot }\end{array}$ & $\begin{array}{l}\text { Effective } \\
\text { tillers/pot }\end{array}$ & $\begin{array}{l}\text { Spike length } \\
(\mathrm{cm})\end{array}$ & $\begin{array}{l}\text { No. of } \\
\text { grains/spike }\end{array}$ & $\begin{array}{l}1000 \text { grain } \\
\text { weight }(\mathrm{g})\end{array}$ & $\begin{array}{l}\text { Grain yield } \\
(\mathrm{g} / \mathrm{pot})(\mathrm{g})\end{array}$ \\
\hline Control & $11.33 \mathrm{a}$ & $31.00 \mathrm{ab}$ & $14.33 \mathrm{a}$ & $41.87 \mathrm{cde}$ & $38.64 a b$ & $49.28 \mathrm{ef}$ \\
\hline Aspergillus flavus RPW 1/3 & $11.00 \mathrm{ab}$ & $36.67 \mathrm{a}$ & $14.70 \mathrm{a}$ & $44.00 \mathrm{abc}$ & $41.74 \mathrm{a}$ & $61.76 \mathrm{a}$ \\
\hline Aspergillus terreus RPW 1/6 & $10.33 \mathrm{ab}$ & $34.33 \mathrm{ab}$ & $14.60 \mathrm{a}$ & $43.87 \mathrm{abc}$ & $40.95 \mathrm{a}$ & $61.40 \mathrm{a}$ \\
\hline Aspergillus terreus RPW 1/9 & $10.67 \mathrm{ab}$ & $36.67 \mathrm{a}$ & $14.47 \mathrm{a}$ & $43.73 \mathrm{abc}$ & $40.31 \mathrm{a}$ & $64.51 \mathrm{a}$ \\
\hline Aspergillus flavus RPW 1/10 & $11.33 \mathrm{a}$ & $33.67 \mathrm{ab}$ & $14.63 \mathrm{a}$ & $40.21 \mathrm{ef}$ & $37.72 \mathrm{ab}$ & $50.18 \mathrm{def}$ \\
\hline Penicillium janthinellum RPWM 2/2 & $10.33 \mathrm{ab}$ & $30.00 \mathrm{ab}$ & $14.37 \mathrm{a}$ & $44.93 \mathrm{ab}$ & $40.84 \mathrm{a}$ & $55.42 b$ \\
\hline Aspergillus niger RZWM 3/1 & $10.67 \mathrm{ab}$ & $32.33 \mathrm{ab}$ & $13.63 \mathrm{ab}$ & $42.00 \mathrm{cde}$ & $38.16 \mathrm{ab}$ & $53.57 \mathrm{bcd}$ \\
\hline Alternaria alternata RZWM 3/2 & $10.67 \mathrm{ab}$ & $30.00 \mathrm{ab}$ & $14.77 \mathrm{a}$ & $45.50 \mathrm{a}$ & $43.54 \mathrm{a}$ & $55.61 \mathrm{~b}$ \\
\hline Alternaria alternata MWM 4/7 & $10.00 \mathrm{~b}$ & $28.67 \mathrm{~b}$ & $14.47 \mathrm{a}$ & $44.93 \mathrm{ab}$ & $37.77 \mathrm{ab}$ & $54.17 \mathrm{bc}$ \\
\hline Penicillium oxalicum MWM 4/9 & $11.00 \mathrm{ab}$ & $32.00 \mathrm{ab}$ & $13.00 \mathrm{~b}$ & $39.07 \mathrm{f}$ & $41.33 \mathrm{a}$ & $50.96 \mathrm{cde}$ \\
\hline Penicillium oxalicum MWM 4/13 & $10.67 \mathrm{ab}$ & $28.67 \mathrm{~b}$ & $14.07 \mathrm{ab}$ & $42.68 \mathrm{bcd}$ & $30.94 b$ & $47.38 \mathrm{f}$ \\
\hline Cladosporium cladosporioides MWM 4/14 & $10.33 \mathrm{ab}$ & $32.33 \mathrm{ab}$ & 14.00ab & $43.27 \mathrm{abc}$ & $38.91 \mathrm{ab}$ & $53.94 \mathrm{bc}$ \\
\hline
\end{tabular}

Small alphabets followed in a column shows significant differences amongst isolates at $5 \%$ level of significance

Table 3 Interactions among four fungal isolates on potato dextrose agar plates

\begin{tabular}{|c|c|}
\hline Interacting isolates & Type of interaction \\
\hline $\begin{array}{l}\text { A. flavus RPW } 1 / 3 \\
\text { A. terreus } \mathrm{RPW} 1 / 6\end{array}$ & Inhibition of growth of both at distance was observed (Deadlock at distance) \\
\hline $\begin{array}{l}\text { A. flavus RPW } 1 / 3 \\
\text { P. pinophilum RPWM } 2 / 2\end{array}$ & $\begin{array}{l}\text { Isolate } P \text {. pinophilum RPWM } 2 / 2 \text { extended its growth towards } A \text {. flavus RPW } 1 / 3 \text {. It is partial } \\
\text { mutual intermingling type of interaction (Fig. } 5 \mathrm{a}, \mathrm{b} \text { ) }\end{array}$ \\
\hline $\begin{array}{l}\text { A. flavus RPW } 1 / 3 \\
\text { A. alternata RZWM } 3 / 2\end{array}$ & $\begin{array}{l}\text { Growth of both the isolates stopped at their contact point. This is deadlock at touching area } \\
\text { type of interaction }\end{array}$ \\
\hline $\begin{array}{l}\text { A. terreus } \mathrm{RPW} 1 / 6 \\
\text { P. pinophilum RPWM } 2 / 2\end{array}$ & $\begin{array}{l}\text { Growth of both the isolates stopped at their contact point. This is deadlock at touching area } \\
\text { type of interaction }\end{array}$ \\
\hline $\begin{array}{l}\text { A. terreus RPW } 1 / 6 \\
\text { A. alternata RZWM } 3 / 2\end{array}$ & $\begin{array}{l}\text { A very prominent clear area was observed between the both isolates. This is deadlock } \\
\text { interaction at distance }\end{array}$ \\
\hline $\begin{array}{l}\text { P. pinophilum } \mathrm{RPWM} 2 / 2 \\
\text { A. alternata } \mathrm{RZWM} 3 / 2\end{array}$ & $\begin{array}{l}\text { These isolates also showed dead lock interaction at distance but distance between isolates is } \\
\text { less can be seen only in reverse plate view }\end{array}$ \\
\hline
\end{tabular}

Fig. 5 Interaction between $A$ flavus RPW $1 / 3$ and $P$. pinophilum RPWM 2/2

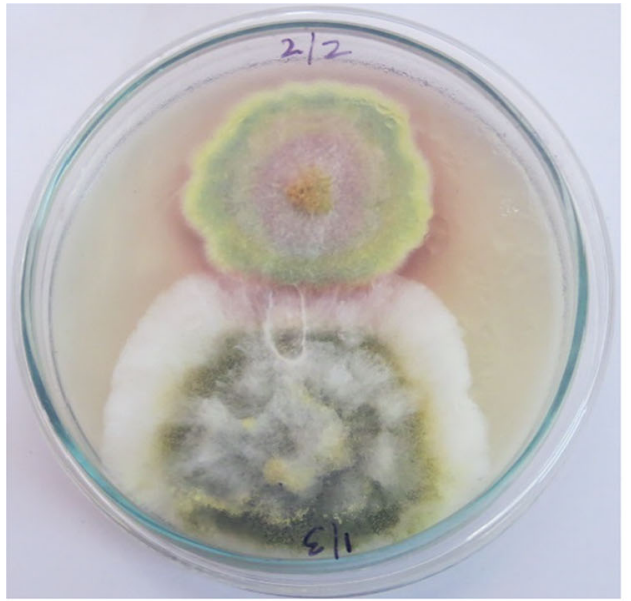

(a) Obverse side view

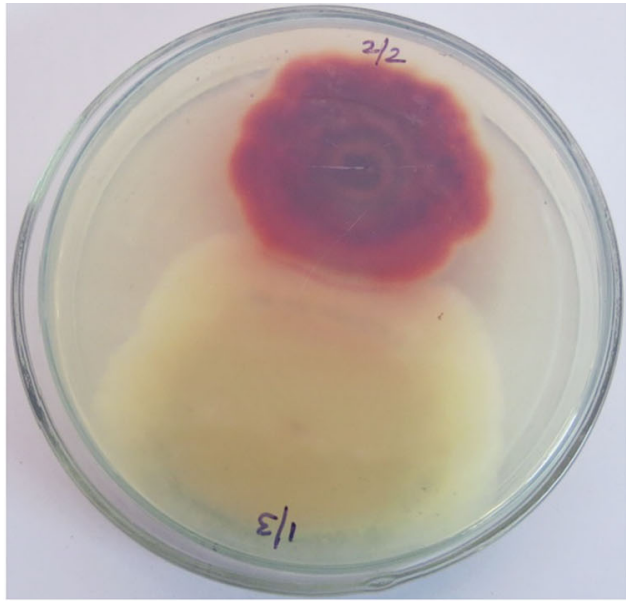

(b) Reverse side view 
pinophilum RPWM 2/2 and A. flavus RPW 1/3) showed antagonism with different types. In the antagonism interaction different extends of deadlock interaction was observed. Fungal isolates A. flavus RPW $1 / 3$ and $P$. pinophilum RPWM $2 / 2$ may interact synergistically as these showed partial mutual intermingling type of interaction (Fig. 5) and may be used in mixed culture for bioconversion of crop residues. Other isolates may also be used solely or may be further tested for their compatibility with other microbial isolates.

\section{Conclusion}

Results from our study showed that fungal isolates from rice-wheat fields can enhance degradation of rice and wheat residues with no adverse effect on wheat growth. Four fungal isolates viz. A. flavus RPW 1/3, A. terreus RPW 1/6, Alternaria alternata RZWM $3 / 2$ and $P$. janthinellum RPWM $2 / 2$ showed higher degradation potential compared to the other isolates as evident from their enzymatic activities, loss of dry mass and cell wall constituents. A consortium of lignocellulolytic fungi comprising Aspergillus flavus RPW 1/3 and Penicillium pinophilum RPWM $2 / 2$ showing partial mutual compatible interaction may prove efficient for degradation of crop residues. Use of native microbes for degradation of crop residues at a fast rate will increase buildup of soil organic matter and other soil physical and chemical properties. The nonpathogenic isolates having high degradative potential are needed to be evaluated under field conditions for their effective use in crop residue decomposition. Fast degradation of lignocellulosic biomass by autochthonous fungi may allow use of normal zero-till machine for timely sowing of wheat into combined harvested rice fields and avoid in situ burning of rice straw.

Acknowledgements The authors acknowledge the support received from Cereal Systems Initiative for South Asia (CSISA) project, International Maize \& Wheat Improvement Centre (CIMMYT), Indian Council of Agriculture Research-Central Soil Salinity Research Institute (ICAR-CSSRI), Karnal, and Kurukshetra University (Kurukshetra) to undertake this study. We are also thankful to Dr. J.K. Ladha, International Rice Research Institute (IRRI) for his suggestions in improving this manuscript.

\section{Compliance with ethical standards}

Conflict of interest The authors declare that they have no conflict of interest.

Open Access This article is distributed under the terms of the Creative Commons Attribution 4.0 International License (http://crea tivecommons.org/licenses/by/4.0/), which permits unrestricted use, distribution, and reproduction in any medium, provided you give appropriate credit to the original author(s) and the source, provide a link to the Creative Commons license, and indicate if changes were made.

\section{References}

Abd-Elzaher FH, Fadel M (2010) Production of bioethanol via enzymatic saccharification of rice straw by cellulase produced by Trichoderma Reesei under solid state fermentation. N Y Sci 3:72-78

Ainsworth GC, Bisby GR (1995) Dictionary of the fungi, Commonwealth Mycological Institute Kew, Surrey, 445

AOAC (1995) Official methods of analysis, 16th edn. Association of Official Analytical Chemists, Arlington

Bajwa HS (2012) Package of practices for crops of Punjab. PAU Printing Press, Ludhiana, pp 1-17

Chang AJ, Fan J, Wen X (2012) Screening of fungi capable of highly selective degradation of lignin in rice straw. Int Biodeterior Biodegrad 72:26-30. doi:10.1016/j.ibiod.2012.04.013

Chavez R, Bull P, Eyzaguirre J (2006) The xylanolytic enzyme system from the genus Penicillium. J Biotechnol 123:413-433. doi:10.1016/j.jbiotec.2005.12.036

Chinedu NS, Nwinyi OC, Okochi VI (2008) Growth and cellulase activity of wild type Aspergillus niger ANL301 in different carbon sources. Can J Pure Appl Sci 2:357-362

Cruz-Hernandeza M, Contreras-Esquivela JC, Larab F, Rodrigueza R, Aguilara CN (2005) Isolation and evaluation of tannin-degrading fungal strains from the Mexican desert. Zeitschrift fur Naturforschung 60:844-848

Dinis MJ, Bezerra RMF, Nunes F, Dias AA, Guedes CV, Ferreira LMM, Cone JW, Marques GSM, Barros ARN, Rodrigues MAM (2009) Modification of wheat straw lignin by solid state fermentation with white-rot fungi. Bioresour Technol 100:4829-4835. doi:10.1016/j.biortech.2009.04.036

Dobermann A, Fairhurst TH (2002) Rice straw management. Better crops Int 16, Sp. Supp. May: 7-9. http://www.ipni.net/ppiweb/ bcropint.nsf

Domsch KM, Gams W, Anderson TH (1980) Compendium of soil fungi, (vol. 1). Academic Press Inc., New York, pp 1-859

Edward K, Johnstone C, Thompson C (1991) A simple and rapid method for the preparation of plant genomic DNA for PCR analysis. Nucl Acids Res 19:1349. doi:10.1093/nar/19.6.1349

Gardes M, Bruns TD (1993) ITS primers with enhanced specificity for Basidiomycetes - application to the identification of mycorrhizae and rusts. Mol Ecol 2:113-118. doi:10.1111/j.1365-294X. 1993.tb00005.x

Gathala M, Kumar V, Sharma PC, Saharawat Y, Jat HS, Singh M, Kumar A, Jat ML, Humphreys E, Sharma DK, Sharma S, Ladha JK (2013) Optimizing intensive cereal-based cropping systems addressing current and future drivers of agricultural change in the northwestern Indo-Gangetic Plains of India. Agric Ecosyst Environ 177:85-97. doi:10.1016/j.agee.2013.06.002

Ghose TK (1987) Measurement of cellulase activities. Pure Appl Chem 59:257-268. doi:10.1351/pac198759020257

Ghose TK, Bisaria VS (1987) Measurement of hemicellulase activities part 1: Xylanases. Pure Appl Chem 59(12):1739-1752. doi:10.1351/pac198759121739

Gilman JC (2001) A Manual of soil fungi, 2nd edn. Biotech Books, New Delhi, pp 1-392

Golueke CG (1992) Bacteriology of composting. Biocycle 33:55-57

Inderjit S, Rawat D, Foy CL (2004) Multifaceted approach to determine rice straw phytotoxicity. Can J Bot 82:168-176. doi:10.1139/b03-137 
Jahromi MF, Liang JB, Rosfarizan M, Goh YM, Shokryazdan P, Ho YW (2011) Efficiency of rice straw lignocelluloses degradability by Aspergillus terreus ATCC 74135 in solid state fermentation. Afr J Biotechnol 10:4428-4435

Jain N, Bhatia A, Pathak H (2014) Emission of air pollutants from crop residue burning in India. Aerosol Air Qual Res 14:422-430. doi:10.4209/aaqr.2013.01.0031

Jin R, Liao H, Xuanming L, Zheng M, Xiong X, Liu X, Zhang L, Zhu $Y$ (2012) Identification and characterization of a fungal strain with lignin and cellulose hydrolysis activities. Afr J Microbiol Res 6(36):6545-6550. doi:10.5897/ajmr12.476

Jorgensen H, Olsson L (2006) Production of cellulases by Penicillium brasilianum IBT 20888: effect of substrate on hydrolytic performance. Enzyme Microb Tech 38:381-390. doi:10.1016/j. enzmictec.2005.06.018

Kanabkaew T, Oanh NTK (2011) Development of spatial and temporal emission inventory for crop residue field burning. Environ Model Assess 16:453-464. doi:10.1007/s10666-0109244-0

Kasana RC, Richa S, Dhar H, Dutt S, Gulati A (2008) A rapid and easy method for the detection of microbial cellulases on agar plates using Gram's Iodine. Curr Micro 57:503-507. doi:10. 1007/s00284-008-9276-8

Kaur A, Sahota PP (2004) Studies on the role of fungal inocula in composting of wheat straw. Asian J Microbiol Biotechnol Environ Exp Sci 6:671-673

Kausar H, Sariah M, Saud HM, Alam MZ, Ismail MR (2010) Development of compatible lignocellulolytic fungal consortium for rapid composting of rice straw. Inter Biodeter Biodegrad 64:594-600. doi:10.1016/j.ibiod.2010.06.012

Krogh KBR, Mørkeberg A, Frisvad JC, Olsson L (2004) Screening genus Penicillium for producers of cellulolytic and xylanolytic enzymes. Appl Biochem Biotechnol 113:389-401. doi:10.1385/ ABAB:114:1-3:389

Kumar AK, Parikh BS (2015) Cellulose-degrading enzymes from Aspergillus terreus D34 and enzymatic saccharification of mildalkali and dilute-acid pretreated lignocellulosic biomass residues. Bioresour Bioprocess 2:7. doi:10.1186/s40643-015-0038-8

Lee S, Jang Y, Lee YM, Lee J, Lee H, Kim GH, Kim JJ (2011) Rice straw decomposing fungi and their cellulolytic and xylanolytic enzymes. J Microbiol Biotechnol 21:1322-1329. doi:10.4014/ jmb.1107.07022

Liao H, Xu C, Tan S, Wei Z, Ling N, Yu G, Raza W, Zhang R, Shen Q, Xu Y (2012) Production and characterization of acidophilic xylanolytic enzymes from Penicillium oxalicum GZ-2. Bioresour Technol 123:117-124. doi:10.1016/j.biortech.2012.07.051

Lundell TK, Makela MR, Hilden K (2010) Lignin-modifying enzymes in filamentous basidiomycetes-ecological, functional and phylogenetic review. J Basic Microbiol 50:5-20. doi:10. 1002/jobm.200900338

Lynch JM, Slater JH, Bennett JA, Harper SHT (1981) Cellulase activities of some aerobic micro-organisms isolated from soil. J Gen Microbiol 127:231-236. doi:10.1099/00221287-127-2-231

Lynd LRWP, Van Zyl WH, Pretorius IS (2002) Microbial cellulose utilization: fundamentals and biotechnology. Microbiol Mol Biol R 66:506-577. doi:10.1128/MMBR.66.3.506-577.2002

Mandels M, Weber J (1969) The production of cellulases. Adv Chem 95:391-414. doi:10.1021/ba-1969-0095.ch023

Maza M, Pajot HF, Amoroso MJ (2014) Post-harvest sugarcane residue degradation by autochthonous fungi. Int Biodeterior Biodegrad 87:18-25. doi:10.1016/j.ibiod.2013.10.020

Meijer M, Houbraken JAMP, Dalhuijsen S, Samson RA, Vries RP (2011) Growth and hydrolase profiles can be used as characteristics to distinguish Aspergillus niger and other black aspergilla. Stud Mycol 69:19-30. doi:10.3114/sim.2011.69.02
Milagres AMF, Lacis LS, Prade RA (1993) Characterization of xylanase production by a local isolate of Penicillium janthinellum. Enzyme Microbial Technol 15:248-253. doi:10.1016/01410229(93)90145-R

Miller GL (1959) Use of dinitrosalicylic acid reagent for determination of reducing sugar. Anal Chem 31:426-428. doi:10.1021/ ac60147a030

Molla AH, Fakhru'l-Razi A, Abd-Aziz S, Hanafi MM, Alam MZ (2001) Invitro compatibility evaluation of fungal mixed culture for bioconversion of domestic wastewater sludge. World $\mathrm{J}$ Microbiol Biotech 17:849-856. doi:10.1023/A:1013844306960

Nagamani A, Kunwar IK, Manoharachary C (2006) Handbook of soil fungi. I.K. International Pvt. Ltd., New Delhi, pp 1-477

Ogbonna AI, Nwadiaro PO, Chuku A, Ogbonna CIC, Onwuliri FC (2015) Cellulase induction in three Aspergillus species isolated from Artemisia annua L. plantation soil using different cellulose substrates. J Appl Biotechnol 3:63-74. doi:10.5296/jab.v3i1. 6738

Peciulyte D (2007) Isolation of cellulolytic fungi from waste paper gradual recycling materials. Ekologija 53:11-18

Reanprayoon P (2011) Rice straw degradation by thermophilic fungi under liquid and solid state fermentation. http://agris.fao.org/ agris-search/search.do?recordID=PH2013000269

Reese ET, Mandels M (1963) Enzymatic hydrolysis of cellulose and its derivatives. In: Whistler RL (ed) Methods carbohydrate chemistry, 3rd edn. Academic Press, London, pp 139-143

Sandhu DK, Arora DS (1985) Laccase production by Polyporus sanguineus under different nutritional and environmental conditions. Experientia 41:355-356. doi:10.1007/BF02004501

Saparrat MCN, Rocca M, Aulicino M, Arambarri AM, Balatti PA (2008) Celtistala and Scutia buxifolia leaf litter decomposition by selected fungi in relation to their physical and chemical properties and lignocellulolytic enzyme activity. Eur J Soil Biol 44:400-407

Saritha V, Maruthi YA (2010) Soil fungi: potential myco remediators of lignocellulosic waste. BioResources 5:920-927

Sarkar S (2015) Management practices for enhancing fertilizer use efficiency under rice-wheat cropping system in the IndoGangetic plains. Innovare J Agric Sci 3:5-10

Shahriarinour M, Ramanan RN, Abdul Wahab MN, Mohamad R, Mustafa S, Ariff AB (2011) Improved cellulase production by Aspergillus terreus using oil palm empty fruit bunch fiber as substrate in a stirred tank bioreactor through optimization of the fermentation conditions. BioResources 6:2663-2675

Sharma A, Sharma R, Arora A, Shah R, Singh A, Pranaw K, Nain L (2014) Insights into rapid composting of paddy straw augmented with efficient microorganism consortium. Int $\mathrm{J}$ Recycl Org Waste Agric 3:54

Sinegani AAS, Emtiazi G, Hajrasuliha S, Shariatmadari H (2005) Biodegradation of some agricultural residues by fungi in agitated submerged cultures. Afr J Biotechnol 4:1058-1061

Sohail M, Ahmad A, Khan SA (2011) Production of cellulases from Alternaria sp. MS28 and their partial characterization. Pak J Bot 43:3001-3006

Song F, Tian X, Fan X, He X (2010) Decomposing ability of filamentous fungi on litter is involved in a subtropical mixed forest. Mycologia 102:20-26. doi:10.3852/09-047

Sorgatto M, Guimarães NCA, Zanoelo FF, Marques MR, PeixotoNogueira SC, Giannesi GG (2012) Purification and characterization of an extracellular Xylanase produced by the endophytic fungu, Aspergillus terreus grown in submerged fermentation. Afr J Biotechnol 11:8076-8084. doi:10.5897/AJB11.2686

Terrasan CR, Temer B, Duarte MC, Carmona EC (2010) Production of xylanolytic enzymes by Penicillium janczewskii. Bioresour Technol 101:4139-4143. doi:10.1016/j.biortech.2010.01.011 
Tuomela M, Vikman M, Hatakka A, Itavaava M (2000) Biodegradation of lignin in a compost environment: a review. Bioresour Technol 72:169-183. doi:10.1016/S0960-8524(99)00104-2

Van Soest PJ, Robertson JB, Lewis BA (1991) Symposium: carbohydrate methodology, metabolism and nutritional implications in dairy cattle. Methods for dietary fiber, neutral detergent fiber and non starch polysaccharides in relation to animal nutrition. J Dairy Sci 74:3583-3597. doi:10.3168/jds.S00220302(91)78551-2

Viji J, Neelenarayanan P (2015) Efficacy of lignocellulolytic fungi on the biodegradation of paddy straw. Int J Environ Res 9:232-252

Vuorinen AH (2000) Effect of bulking agent on acid and alkaline phosphomonoesterase and b-D-glucosidase activities during manure composting. Bioresour Tech 75:113-138. doi:10.1016/ S0960-8524(00)00042-0

Wan C, Li Y (2010) Microbial delignification of corn stover by Ceriporiopsis subvermispora for improving cellulose digestibility. Enzym Microb Technol 47:31-36. doi:10.1016/j.enzmictec. 2010.04.001
Ward OP, Qin WM, Dhanjoon J, Ye J, Singh A (2005) Physiology and biotechnology of Aspergillus. Adv Appl Microbiol 58:1-75. doi:10.1016/S0065-2164(05)58001-8

Wipusaree N, Sihanonth P, Piapukiew J, Sangvanich P, Karnchanatat A (2011) Purification and characterization of a xylanase from the endophytic fungus alternaria alternata isolated from the Thai medicinal plant, Croton oblongifolius roxb. Afr J Microbiol Res 5:5697-5712. doi:10.5897/ajmr11.1037

Yin ZW, Fan BQ, Ren P (2011) Isolation and identification of a cellulose degrading fungus Y5 and its capability of degrading wheat straw. Huan Jing Ke Xue 32:247-252

Zeng GM, Yu HY, Huang HL, Chen YN, Huang GH (2006) Laccase activities of a soil fungus Penicilluim simplicissimum in relation to lignin degradation. World J Microbiol Biotechnol 22:317-324. doi:10.1007/s11274-005-9025-0

Zhu N (2007) Effect of low initial C/N ratio on aerobic composting of swine manure with rice straw. Bioresour Technol 98:9-13. doi:10.1016/j.biortech.2005.12.003 